\title{
Provisions and Effectiveness of Continued Staff Development Programmes for Professionals in University Libraries in East India
}

\author{
Arun Kumar \\ Fortune Institute of International Business \\ Vasant Vihar, New Delhi, India \\ arunsuraj@yahoo.com; arunkamala@gmail.com
}

\begin{abstract}
One of the greatest challenges that academic and research libraries face today is to prepare the staff working in these organizations for the future. Preparation of library staff requires serious attention to the human resource programmes in libraries and consideration of the development needs and interests of staff at all levels, from at the top the University Librarian to the lowest level the Library Attendant. Human resource planning requires a strategic approach, which focuses on both the immediate issues and considers future needs. Library Managers and the Library Authority need to be adept at identifying the human resources issues in the ir organizations; able to design and implement development programmes, polic ies and procedures, to address these issues in a timely and meaningful way; and willing to commit the necessary resources to support the full development of all library staff.
\end{abstract}

Keywords: library, staff development

\section{Introduction}

Library and Information professionals are concerned with collecting, organizing and serving rapid proliferation of research and developments in all spheres of knowledge. Thus, the role of library and information professionals is becoming more and more important in the welfare of the society. They make use of their professional skills, various techniques, procedures, methods, and technology, and these are ever changing and advancing. To keep pace with the ever changing needs of the library users and advances taking place in the ir specialized professional fie ld, human resource in libraries need to update and upgrade their professional knowledge and skills at regular intervals. For constantly developing library manpower in a systematic way is termed as 'library staff development process'. It covers the systematic development of skills, competence and attitudes of employee's to enhance organizational effectiveness.

Material published as part of this publication, either on-line or in print, is copy righted by the Informing Science Institute. Permission to make digital or paper copy of part or all of these works for personal or classroom use is granted without fee provided that the copies are not made or distributed for profit or commercial advantage AND that copies 1) bear this notice in full and 2) give the full citation on the first page. It is permissible to abstract these works so long as credit is given. To copy in all other cases or to republish or to post on a server or to redistribute to lists requires specific permission and payment of a fee. Contact Publisher@InformingScience.org to request redistribution permission.

\section{Statement of Problem}

The title of the problem contains three main terms, namely, (i) Staff Development, (ii) Professionals, and (iii) Provisions \& Effectiveness. The contents and imports of these terms are explained as follows. 


\section{Definitions of Terms}

Staff Development is taken to mean: "A purposive effort intended to strengthen the library's capability to fulfill its mission effectively and effic iently by encouraging and providing for the growth of its human resources" (Conroy, 1978. p. xv).

The library staff development programme provides opportunities for individuals to expand the ir knowledge and experience in the library and information field. Participation in the staff development programme, unlike many other training and development programmes, is staff-initiated.

The staff development programme enables staff members to develop a range of skills within, and a broader perspective of their area of work, thus creating a more versatile staff better able to meet the changing needs of the university community.

Career Advancement: "A career is usually characterized as developing over a period of years and involving progressive ly more responsible roles within an organization or a profession at large" (Helm, 1982).

Thus, a library definition of staff development serves several purposes. A definition (or lack of one) communicates the philosophy of the library administration toward continuing staff development programmes and determines the role of planners, supervisors, and participants. A definition also provides a framework for evaluation of staff development efforts. Without thoughtful attention to goals and desired outcomes, the success of staff development tends to be measured in terms of the number of attendees or number of workshops presented rather than in terms of needs met, problems solved, or efficiencies gained (Painter, 1992).

Staff Development: What it is not: Staff development is neither continuing education, which is a life long process and usually the responsibility of each individual staff member, nor a break from work.

What it is: Staff development is a programme, which guides and encourages employees to develop their skills and capabilities on a continuing basis. The intent is to improve the performance of both the individuals and the organization and to maximize staff effectiveness. Staff development serves institutional needs and enhances the ability of the organization to meet its goals. To put it simply, it is an effort to help employees learn how to do their jobs better.

Staff development may or may not include career development. As libraries move in new directions, however, staff-development programmes can assist staff in preparing for changes in their present jobs. It also can prepare them to assume new responsibilities within the library (Paulk, 1992).

Merit Promotion Scheme: The Merit Promotion Scheme, subsequently redesigned by the UGC in 1984 as Career Advancement Scheme, could be a timely provision for career development of university library professionals. However, the UGC recommendation could be implemented only in a few universities of various states.

Professional Staff. 'Professional Staff' means the library staff members, who possess professional qua lifications and doing professional jobs in a library. To begin with the present study, (i) the Head of the University Library, the Deputy Librarians and the Assistant Librarians have been included in the category of professional staff. However, the staff, below such positions but possessing higher professional qua lifications, namely, from Professional Assistants to Library Assistants, has also been kept under the purview of this study.

Provisions \& Effectiveness. The term 'Provisions' implies all the channels and steps, facilities made available to the staff by different libraries and library authority having concern to grant opportunities to develop the professional knowledge, skills and effic iency of the library staff. 'Ef- 
fectiveness' means a critical appreciation of deploying such provis ions to benefit library staff in their development through staff development activities and their performance.

\section{Prerequisites of Staff Development}

The extent of management support has a major influence on the results of a training programme. A lack of support is a common reason why skills learned in the classroom fail to transfer to the workplace. Without management endorsement, training is more likely to be perceived as a break from work and little else. It is crucial that trainers understand the role that managers play in the transfer process and involve them in the planning and preparation stages (Carver, 1992).

Further, the staff development of library professionals requires certain amount of facilitating privileges, such as,

- Study Leave,

- Academic Leave,

- Providing financial support for participation in conferences, seminars, workshops,

- In-service Training Programmes, and

- Deputing library staff for admission to higher education.

\section{Objectives of Study}

The objectives of the proposed study are as follows.

To examine the provisions made for staff development in university libraries;

To assess the staff development needs of professionals in university libraries .in India.

To correlate the development needs of the professionals working in univers ity libraries and the provisions for the development.

To examine the effectiveness of available staff development activities for the professionals working in university libraries in three states, namely, Bihar, Orissa and West Bengal.

\section{Hypotheses}

Based on available literature and observations made on the prevailing conditions, certain hypotheses were formulated. It is proposed to test such null hypotheses, given as follows.

Hypothesis 1: There is no difference in the perception of University Librarians with that of professionals in other categories working in university libraries, so far as their preference for various staff development activities is concerned.

Hypothes is 2: There is no difference in the perception of University Librarians with that of professionals in other categories working in university libraries, so far as their preference for need based topics is concerned.

Hypothes is 3: The professionals working in the university libraries, give preference to 'self' over 'other staff', so far as the staff development opportunities are concerned.

\section{The Response}

Assuming that each one of 42 university libraries may have minimum staff of one University Librarian (UL), one Deputy Librarian (DL), two Assistant Librarians (AL), two Professional Assis- 
tants (PA) and three Library Assistants, in all, nine sets of questionnaires were sent in one envelope addressed to the University Librarian of the concerned university.

While collecting response, it was found that, an Assistant Librarian or even a Professional Assistant heads some of these university libraries. Surprisingly enough, part time staff or ad hoc staff is running a few university libraries. Hence, there is glaring difference in number of response from different categories of professionals.

The data collected from 186 respondents has been organized, analyzed and presented in Table 1,

Table 1. Staff Cate gory-wise Analys is of Professionals' Response (N=378)

\begin{tabular}{|l|c|c|c|c|}
\hline $\begin{array}{c}\text { Staff } \\
\text { Category }\end{array}$ & $\begin{array}{c}\text { Number of } \\
\text { Questionnaires }\end{array}$ & $\begin{array}{c}\text { Number of } \\
\text { Response }\end{array}$ & $\begin{array}{c}\text { Percent } \\
\text { Response }\end{array}$ & $\begin{array}{c}\text { Percent of Total } \\
\text { 186 Response }\end{array}$ \\
\hline UL & 42 & 12 & 28.57 & 06.45 \\
\hline DL & 42 & 10 & 23.80 & 05.37 \\
\hline AL & 84 & 57 & 67.85 & 30.64 \\
\hline PA & 84 & 39 & 46.42 & 20.96 \\
\hline Others & 126 & 68 & 53.96 & 36.55 \\
\hline Total & $\mathbf{3 7 8}$ & $\mathbf{1 8 6}$ & $\mathbf{4 9 . 2 0}$ & $\mathbf{1 0 0 . 0 0}$ \\
\hline
\end{tabular}

Explanation:

1. 'Others' includes members of library staff who possess professional qualifications, but who are working in lower positions, such as, Semi-Professional Assistants, Library Assistants, Cataloguers, Classif iers, Computer-In-Charge.

Table 1 shows the poverty of response from the senior professionals working in the university libraries. The situation is alarming to the extent that the staff in the lower category of PAs and Others is made to perform the jobs and responsibilities of UL, DL and AL. In the two university libraries in Bihar, none is having even a single regular staff, and one library is managed by staff engaged on part time basis, whereas another library is being run by staff engaged on ad hoc basis. However, the situation was found better, though the size of library staff falls short of the required number according to work-load in the library, in the states of West Bengal and Orissa.

\section{Recommendation}

The required number of posts of library staff at all levels need to be created and filled up in accordance with the work-load in the university library.

\section{Testing of Hypotheses}

The pre-set hypotheses are being tested by using ranking method and by working out differences in the preferences and positive interest shown by the respondents on various issues pertaining to $\mathrm{SDP}$, given as follows.

Hypothesis 1: There is no difference in the perception of University Librarians with that of professionals in other categories working in university libraries, so far as their preference for various staff development activities is concerned. 
Table 2: Summary of Ranks Given by Professionals to Various Programmes

\begin{tabular}{|l|c|c|c|c|c|}
\hline \multicolumn{1}{|c|}{ Programme } & $\begin{array}{c}\text { UL/ } \\
\text { Rank }\end{array}$ & $\begin{array}{c}\text { DL/ } \\
\text { Rank }\end{array}$ & $\begin{array}{c}\text { AL/ } \\
\text { Rank }\end{array}$ & $\begin{array}{c}\text { PA/ } \\
\text { Rank }\end{array}$ & $\begin{array}{c}\text { Others/ } \\
\text { Rank }\end{array}$ \\
\hline In-Service Training & UL 1 & DL 3 & AL 5 & PA 4 & Oth 4 \\
\hline Enhancing Qualifications & UL 1 & DL 2 & AL 2 & PA 1 & Oth 1 \\
\hline Staff Meetings & UL 1 & DL 1 & AL 3 & PA 2 & Oth 2 \\
\hline Shared Decision Making & UL 2 & DL 1 & AL 6 & PA 2 & Oth 3 \\
\hline Short Term Courses & UL 2 & DL 1 & AL 1 & PA 3 & Oth 1 \\
\hline Library Visits & UL 3 & DL 2 & AL 4 & PA 2 & Oth 2 \\
\hline Sending on Deputation & UL 3 & DL 3 & AL 4 & PA 4 & Oth 4 \\
\hline Research Studies & UL 3 & DL 1 & AL 2 & PA 5 & Oth 5 \\
\hline Long Duration Courses & UL 4 & DL 4 & AL 1 & PA 2 & Oth 1 \\
\hline
\end{tabular}

Table 2 summarizes the ranks given by the respondents to various activities and programmes of development of professionals, in different categories, working in university libraries. The rank given shows the preferential order given by the respondents to a particular SDP. A study of the data presented in Table 1.5.1 reveals that there is significant difference between the preferences shown by the University Librarian and professionals of various other categories (DL, AL, PA, Others). Therefore Null Hypothesis-1 has been rejected.

Thus, the study makes clear that there is significant difference in the preference for various staff development programmes, given by the University Librarians and other professionals working in the university libraries.

Hypothesis 2: There is no difference in the perception of University Librarians with that of professionals in other categories working in university libraries, so far as their preference for need based topics is concerned.

Table 3: Summary of Ranks Given by Professionals to Various Topics of SDP

\begin{tabular}{|l|c|c|c|c|c|}
\hline \multicolumn{1}{|c|}{ Topic for SDP } & $\begin{array}{c}\text { UL/ } \\
\text { Rank }\end{array}$ & $\begin{array}{c}\text { DL/ } \\
\text { Rank }\end{array}$ & $\begin{array}{c}\text { AL/ } \\
\text { Rank }\end{array}$ & $\begin{array}{c}\text { PA/ } \\
\text { Rank }\end{array}$ & $\begin{array}{c}\text { Others/ } \\
\text { Rank }\end{array}$ \\
\hline Public Relations & UL 1 & DL 1 & AL 6 & PA 8 & Others 5 \\
\hline Team Building & UL 1 & DL 1 & AL 8 & PA 8 & Others 10 \\
\hline Time Management & UL 1 & DL 1 & AL 5 & PA 10 & Others 12 \\
\hline $\begin{array}{l}\text { Relations with Higher } \\
\text { Management }\end{array}$ & UL 1 & DL 2 & AL 13 & PA 11 & Others 8 \\
\hline $\begin{array}{l}\text { Profes Consul to Library } \\
\text { Management }\end{array}$ & UL 1 & DL 1 & AL 7 & PA 12 & Others 9 \\
\hline Leadership & UL 2 & DL 2 & AL 7 & PA 9 & Others 7 \\
\hline Management Skills & UL 2 & DL 1 & AL 9 & PA 1 & Others 1 \\
\hline Conflict Management & UL 2 & DL 1 & AL 9 & PA 12 & Others 14 \\
\hline
\end{tabular}




\begin{tabular}{|l|c|c|c|c|c|}
\hline System Study & UL 2 & DL 1 & AL 8 & PA 8 & Others 6 \\
\hline Lib Automation & UL 2 & DL 1 & AL 2 & PA 3 & Others 2 \\
\hline Technical Writing & UL 2 & DL 1 & AL 2 & PA 11 & Others 11 \\
\hline Commun Skills & UL 3 & DL 2 & AL 5 & PA 2 & Others 4 \\
\hline Performance Skills & UL 3 & DL 2 & AL 3 & PA 7 & Others 5 \\
\hline Grievance Handling & UL 3 & DL 3 & AL 10 & PA 6 & Others 13 \\
\hline Stress Management & UL 1 & DL 2 & AL 13 & PA 13 & Others 16 \\
\hline Lib Office Auto & UL 3 & DL 1 & AL & PA 4 & Others 3 \\
\hline Interview Tech & UL 3 & DL 1 & AL 4 & PA 5 & Others 2 \\
\hline Copyright/IPR & UL 3 & DL 2 & AL 11 & PA 9 & Others 15 \\
\hline Marketing & UL 4 & DL 4 & AL 12 & PA 11 & Others 12 \\
\hline
\end{tabular}

Table 3 summarizes the ranks given by the respondents to various topics/ contents of programmes for development of professionals, in different categories, working in university libraries. The rank given shows the preferential order given by the respondents to a particular topic. A study of the data presented in Table 3 reveals that there is significant difference between the preferences shown by the University Librarian and professionals of various other categories (DL, AL, PA, Others). Therefore Null Hypothesis-2 has been rejected.

Thus, the study makes clear that there is significant difference in the preferences for topics for various staff development programmes, given by the University Librarians and other professionals working in the university libraries.

Hypothesis 3: The professionals working in the university libraries give preference to 'self' over 'other staff', so far as the staff development opportunities are concerned.

Table 4: Professionals Pre fe rring 'Self' over 'Other Staff' (N=186)

\begin{tabular}{|l|c|c|c|c|}
\hline \multirow{2}{*}{$\begin{array}{c}\text { Development Opportunities for } \\
\text { 'Self' / 'Staff' }\end{array}$} & \multicolumn{2}{|c|}{ Positive } & \multicolumn{2}{c|}{ Negative } \\
\cline { 2 - 5 } & Freq & $\begin{array}{c}\text { Per } \\
\text { Cent }\end{array}$ & Freq & $\begin{array}{c}\text { Per } \\
\text { Cent }\end{array}$ \\
\hline Development Opportunities for Self & 160 & 86.02 & 26 & 13.98 \\
\hline Development Opportunities for Staff & 146 & 78.49 & 40 & 21.51 \\
\hline
\end{tabular}

Table 4 shows that larger majority $(86.02 \%)$ of respondents has kept 'self" over the $(78.49 \%)$ respondents favouring development opportunities for 'other staff' in their libraries. Therefore, Null Hypothesis-3 is found positive and accepted.

Thus, the study makes clear that the library professionals, like any ordinary human being, are subjective in their approach towards staff development opportunities by keeping the ir 'self' above their coworkers. There is need to make the professionals aware about the development needs of all members of library staff. 


\section{Findings}

1. The study makes clear that there is significant difference in the preference for various staff development activities, given by the University librarians and by other professionals working in the university libraries.

2. There is significant difference in the preference for need-based topics for various staff development programmes, given by the University Librarians and by other professionals working in the university libraries.

3. Library professionals, like any ordinary human be ing are subjective in the ir approach towards staff development opportunities by keeping their self above the ir 'coworkers'. There is need to make the professionals aware about the development needs of all members of library staff.

\section{Conclusions:}

Library Managers and the Library Authority need to be adept at identifying the human resources issues in the ir organizations; able to design and implement development programmes, polic ies and procedures, to address these issues in a timely and meaningful way; and willing to commit the necessary resources to support the full development of all library staff and library services..

\section{References}

Carver. D. A. (1992). How people apply what they learn: Transfer of training. In E. F. Avery, T. Dahlin, D. A. Carver, \& T. C. Dahlin (Eds.), Staff development: A practical guide (2nd ed.) (p. 8). Chicago and London: A merican Library Association

Conroy, B. (1978). Library staff development and continuing education: Principles and practices. Littleton, Colorado, Libraries Un limited.

Helm, K. M., \& Estabrook, L S. (1982). Career patterns of librarians. Drexel Library Quarterly. 6, 35-50.

Painter, F. O. (1992). Definitions of staff development: A sampling. In E. F. Avery, T. Dah lin, D. A. Carver, \& T. C. Dahlin (Eds.), Staffdevelopment: A practical guide (2nd ed.) (p. 89). Chicago and London: A merican Library Association.

Paulk, J. T. (1992). How to gather support. In E. F. Avery, T. Dahlin, D. A. Carver, \& T. C. Dahlin (Eds.), Staff development: A practical guide (2nd ed.) (p. 29-30). Chicago and London: American Library Association.

\section{Biography}

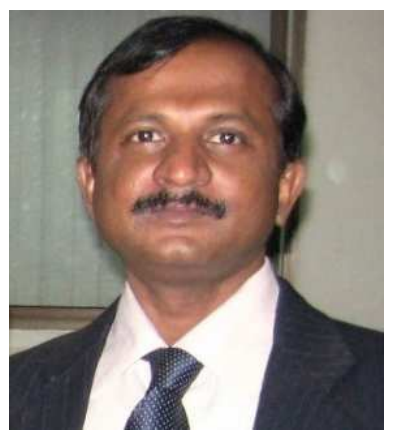

Dr. Arun Kumar is employed as Librarian at the Fortune Institute of International Business (FIIB), New Delhi (India). He has more than 14 years of experience working as librarian at the FIIB. Dr. Kumar has received his M.A. in Political Science and Ph.D. in Library Information Science all from the University of Delhi (India). He is the life member of several Professional Societies including Indian Library Association (ILA), Ranganathan Research Circle (RRC), and Society for Information Science (SIS). He has also attended several conferences in India related to Library Information Science. He has published several papers in conference proceedings. 